\title{
Design of a manually operated paper recycling machine.
}

\author{
Panashe Mombeyarara, Tauyanashe Chikuku, and Tawanda Mushiri* \\ Department of Mechanical Engineering, University of Zimbabwe, P.O Box MP167 Mount \\ Pleasant, Harare, Zimbabwe \\ \{tawanda.mushiriegmail.com\}
}

\begin{abstract}
Paper is used daily with learning institutions such as universities and schools being the main consumers. Due to its single usage it ends up being disposed hence most of the paper waste remains idle and unutilized although it is a valuable resource. Therefore, this paper explores the design of a cheap and efficient manually operated paper recycling machine. The design used integration of acquired knowledge on the recycling technology, existing manually operated and available paper recycling machines to form a cheap but efficient paper recycling machine. The benefits of the machine are not only centred on the merits of recycling paper but by the in-cooperation of the manually driving system which will also curb the high unemployment rates in developing countries. Due to the design being not $100 \%$ efficient due to the gear box, belt and chain transmission, the estimated efficiency is equal to $90 \%$ but using the $90 \%$ for design, the design power input is 450 watts and since an average person can produce 100 Watts constantly therefore 5 people are necessary to drive the machine.
\end{abstract}

Keywords: Design, manually operated, paper recycling, machine.

\section{Introduction}

\subsection{Background to the Study}

Paper is material manufactured in thin sheets from the pulp of wood or other fibrous substances, used for writing, drawing, or printing on, or as wrapping material. According to SILKROAD, paper making is one of the first inventions done by the Chinese in 105 A.D. The ability to mass produce paper has resulted in the development of writing as a means to pass down information through the ages. It is still a major way that our culture stores information and while the benefits of digital storage are many, paper still offers some vital advantages such as its crucial involvement in all stages of education (learning) and safe storage of information since there is no need for file conversions and paper is immune to hacking, and the fact that it can be produced sustainably. It also holds a special place in history, and many of our latest discoveries about the past are made by investigating the written remains of culture that has been preserved until now. Due to the improved technological

ACRID 2017, June 20-21, Victoria Falls, Zimbabwe

Copyright (C) 2017

DOI 10.4108/eai.20-6-2017.2270754 
advances in communications people have taken a blind towards the consequences of disposal of used papers both proper and improper without the consideration that paper is still the most important means through which documentation, advertisement, communication and mostly education is carried out.

The improper disposal and ignoring the reutilization of paper (recycling) leads to environmental degradation in various ways such as landfills, air and land pollution. The Environmental Management Agency (EMA) in Zimbabwe has already elaborated that waste inappropriate solid waste management practices in schools in Zimbabwe, both in rural and urban communities constitute one of the major factors leading to declining environmental health standards.

Using the UNIVERSITY OF ZIMBABWE (UZ) as a case study, used papers have become a menace leading to landfills and degrading the beauty of the campus. The Department of Works at UZ also burns used papers which lead to air pollution through release of soot, ink and dye particles. An important note is that most used paper is of high grade (bond/copy paper) which is an advantage since recycled paper from high grade papers result in high-medium grade paper.

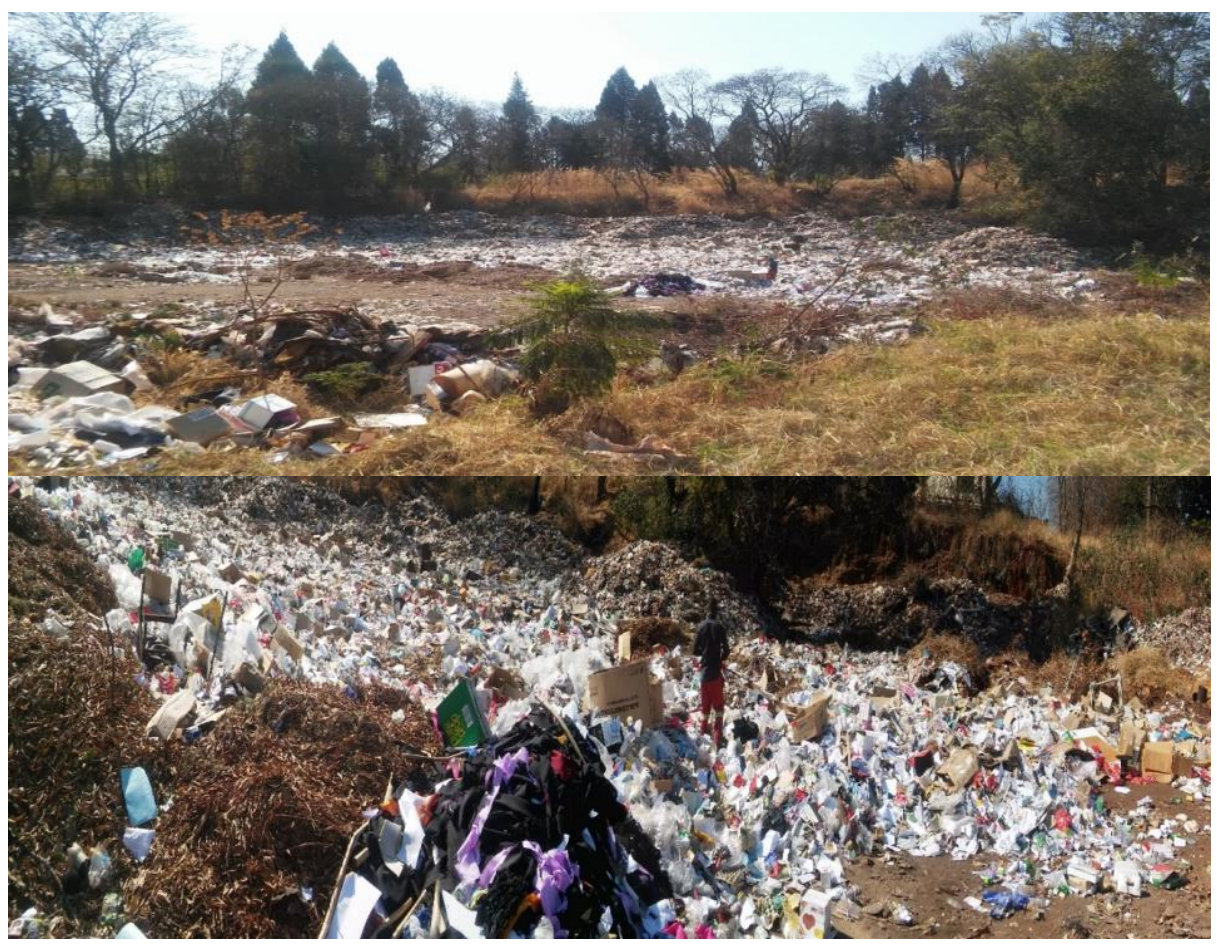

Fig. 1. Shows images of the University of Zimbabwe dump site behind Crop Science buildings, Courtesy of Samsung Phone Camera on 24 August 2016.

The university accommodates approximately 15000 students and if each student throws away 2 sheets of used paper daily it implies that at least 30000 sheets of paper. 
The PRO CARTON Website states that "Laboratory work suggests that fibres can be recycled between $5-7$ times". Venditti in his presentation states that paper recycling recovery can reach as high as $73 \%$. Using the proposal that the recovery rate of used paper through recycling is $73 \%$ and the market value of medium quality paper is $\$ 3$ for 500 sheets, its means the university can generate $\$ 11800$ worth of paper per semester (90 days). That is not the end point but during examination students often dispose at least 2 used counter books (96 pages per counter book) meaning that the project has the potential to generate a further $\$ 12600$ worth of paper per semester. The paper used to write examinations can be recycled and using the assumption that each student writes at least 4 courses each semester meaning 24 sheets of paper are used if recycled using the same $73 \%$ recovery rate, the university can generate at least $\$ 1500$. If the project becomes successful the university is able to generate a minimum of $\$ 25900$ worth of recycled paper with option to further recycling opportunities during winter school. The project can be implemented in institutions such as schools, universities and companies. According to The Herald (2012), there are approximately 5700 primary schools and 2300 secondary schools in Zimbabwe. Imagine the impact it will have in not only Zimbabwe but the African continent and other developing countries.

\section{Literature Review}

\subsection{Process Overview}

The manufacture of recycled paper in conducted according to the following follow chart.

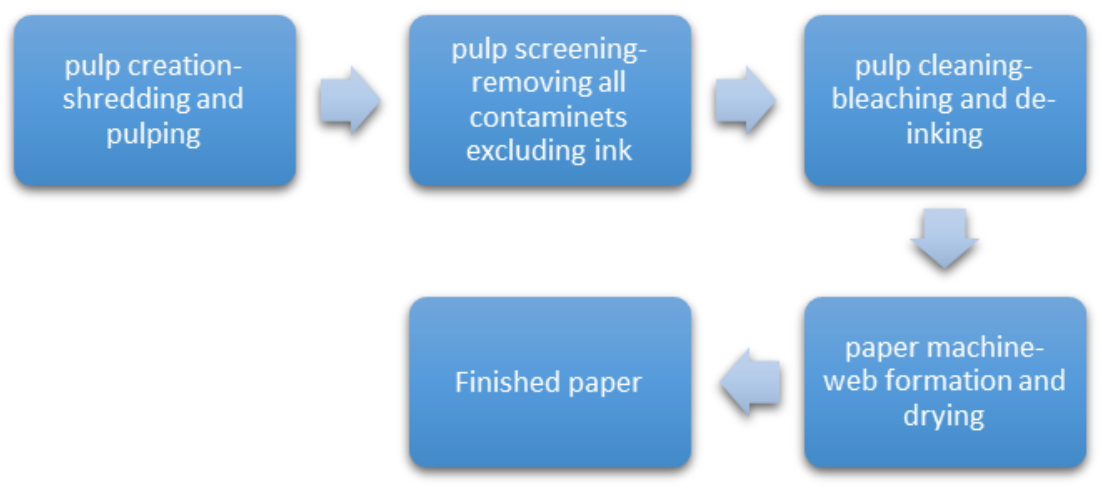

Fig. 2. Process flow in the paper

Paper Online describes recycled paper as a type of paper that completely or partially consists of recycled fibres. These fibres can have very different origins and therefore also very different characteristics when it comes to being a component in new paper. Newsprint, tissue and paperboard are the products primarily produced using recycled paper as raw material. Waste paper is placed in a pulper - a huge tank that liberates 
the paper fibres from the paper web by agitation with large quantities of water - and broken down to slurry. Pulping is the act of processing wood (or other plant) to obtain the primary raw material for making paper, usually cellulose fibre. Also Princeton University describes it as the process is aimed at removing as much lignin (Lignin is an organic substance binding the cells, fibres and vessels which constitute wood and the lignified elements of plants, as in straw) as possible without sacrificing fibre strength, thereby freeing the fibres. The machine design is aimed at converting pulp into paper.

According to Olson and Pflueger (2007, pg.1), screening is the process of contaminant removal from waste paper in order to cope up with the raw material quality decrease and the quality demands of the papermaker. Contaminates include coarser fibres, foreign matter, plastic tape, staple pins and dirt as like pieces of bark, digester brick, cement. According to the Pulp Paper Mill website there are various factors that affect screening performance such as stock consistency, type of fibre, type and size of holes, type of plate cleaning mechanism, level of coarse fibre, foreign matter, rejection rate, flow configuration, flow rate and stock temperature. Water (affects consistency) has an important function in whole the steps in the pulp screening. In screening section, water acts as a conveyer for the fibre.

According to Jiang and Mag (2000, pg. 1-2) De-inking is a separation process to remove inks and other non-fibrous contaminants from waste-papers. The key in the deinking process is the ability to detach ink from the fibres. This is achieved by a combination of mechanical action and chemical means and these are by washing and flotation process.

The waste paper is put into a pulper with a large quantity of water and broken down into a slurry. Contaminates or 'contraries' such as staples and plastic are removed by wire mesh machines and a mechanical action.

According to Drelich et.al flotation is one of the primary methods used to de-ink printed-paper pulp and it works by collecting dispersed ink particles on air bubbles and trapping them in a froth layer. Flotation de-inking is a selective separation process that utilizes the difference of surface physicochemical properties between the ink and fibre. Flotation chemicals are fed to the wastepaper slurry to render the ink particles selectively more hydrophobic and hence to increase the floatability. When the air bubbles are sparged into the flotation cell containing the wastepaper slurry, the ink particles get attached to the air bubbles due to their relatively high hydrophobicity and are floated to the surface of suspension, and the hydrophilic fibres remain in the water phase.

Hart and Rudie (2012) describes bleaching as the destruction of colorants in inks and the brightening of the pulp using bleaching agents such as hydrogen peroxide and sodium dithionite added during the pulping step and/or in a separate bleaching step. Bleaching is typically used to brighten recovered pulp for the production of higher quality graphic papers such as improved newsprint, for other high brightness recycled printing papers and for hygiene papers.

It is a multicomponent continuous-operation aggregate on which paper and several types of cardboard are made from a highly dilute aqueous suspension of fibres. The prepared paper pulp, at a concentration of approximately 3-4 percent, is transferred by means of a pump from the pulp processing compartment to the machine chest and then to the paper machine. The pulp is first diluted with white water (because of 
dehydration of the paper pulp on the wire screen of the paper machine to a concentration of 0.1-1.5 percent) and then passed to the head box. The head box allows for the uniform distribution of the pulp on to the felts in which the paper web is continuously formed from a dilute suspension and on which the first portion of excess water is removed then to the press part were the dehydration and thickening of the web take place after which in goes to the drying part for final moisture removal and lastly the finishing end, in which the web undergoes the necessary processing to give it gloss, density, and smoothness. Figure 3 shows existing machines used in recycling.

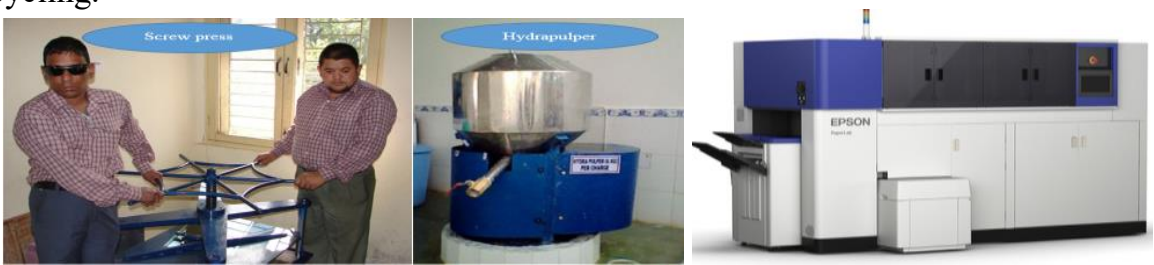

Fig. 3. Current existing machines a. Tera mek V machine and b. Epson Paper Lab

\section{Research Methodology}

In order to come up the design sufficient in-depth research was done using online sources, journals, books, consultations and industrial visits. Three concepts were then generated and a suitable solution was chosen. The chosen solution was then developed and necessary calculations were also done. The modified design was then drawn, modelled and simulated using CAD softwares such SolidWorks 2016 and AutoCAD Inventor.

Table 1. Machine Specification of the recycling machine

\begin{tabular}{ll} 
Capacity & $170 \mathrm{~kg} /$ day \\
Water & $17 \mathrm{~m}^{3} /$ day \\
Area requirement & $20 \mathrm{~m}^{2}$ \\
Paper machine man power & 5 people (max) \\
Charge & $3 \mathrm{~m}^{3} /$ charge \\
Pump & $<1 \mathrm{KW}$ \\
Size of paper & $885 \mathrm{~mm}$-width ; length $>0.5 \mathrm{~m}$ \\
Hydrapulper & Not included in design \\
Flotation and bleacher cells & Turbine agitated (mixed) or $45^{\circ}$ pitched turbine \\
& blade \\
\hline
\end{tabular}

\section{Results and discussion}

\subsection{Design}




\section{Sieve drum}

Volume of sieve drum $=$ cross section area $\mathrm{x}$ length $=5.58 \times 10^{-3} \mathrm{~m}^{3}$; Mass of sieve drum $=$ density $x$ volume $=5.58 \times 10^{-3} \times 7800=43.6 \mathrm{~kg}$; Moment of inertia $\mathrm{I}=\mathrm{mr}^{2} / 2=$ $68.88 \times\left(250 \times 10^{-3}\right)^{2} / 2=2.1525 \mathrm{kgm}^{2} ;$ Required angular acceleration $=2.72 \mathrm{rads}^{-2}$, for attaining $52 \mathrm{rev} / \mathrm{min}$ in 2 seconds; Torque $=\mathrm{I} \alpha=2.1525 \times 2.72=5.8548 \mathrm{Nm}$; Require power to rotate sieve drum $=\mathrm{Tw}=5.8548 \times 5.45=\mathbf{3 1 . 9}$ Watts.

\section{$\underline{\text { Turbine }}$}

Finding the required power to facilitate mixing in flotation cell and or bleaching cell; $\mathrm{P}=\mathrm{k \rho n}^{3} \mathrm{D}^{5}, \mathrm{k}=$ is a constant give as 4.80 for curved turbine blades; $\rho=$ density of pulp, $\mathrm{n}=$ revs $/ \mathrm{sec}, \mathrm{D}=$ diameter of turbine.... For turbulent flow; $\mathrm{P}=4.80 \times 997.78 \times$ $0.5^{3} \times 0.8^{5}=196.17$ Watts for each flotation or bleacher cell. The $45^{0}$ pitched turbine blade can also be used to provide axial mixing flow where the new diameter of impeller $=0.5$ for a baffled smaller tank and $n=1.5$ revs per second. The required power for power number $=1.5$ would be $\mathbf{1 5 8}$ watts

\section{Head box and pump}

Required mass flow rate $=0.9339 \mathrm{~kg} / \mathrm{s} ;$ Volumetric flow rate $=$ mass flow rate $/$ density $=0.9339 / 997.84=0.936 \times 10^{-3} \mathrm{~m}^{3} / \mathrm{s}$; hence it will require less than one hour to empty the tank; Static head $=1.6 \mathrm{~m}, \mathrm{k}=0.45$ for $90^{0}$ angle elbow, $\mathrm{k}=0.15$ for sharp area reduction where $\mathrm{k}$ is the velocity head loss; $\mathrm{Q}=\mathrm{Av}$ therefore $\mathrm{v}=\mathrm{Q} / \mathrm{A}=0.936 \times 10^{-}$ $3 / 8.85 \times 10^{-3}=105.76 \times 10^{-3} \mathrm{~m} / \mathrm{s}$; Velocity head $=\mathrm{u}^{2} / 2 \mathrm{~g}=\left(105.76 \times 10^{-3}\right)^{2} / 92 \times 9.81=$ 0.570 ; Therefore total velocity head losses $=0.57 \times(2 \times 0.45+0.15)=0.598 \mathrm{~m}$; Reynolds number, $\mathrm{Re}=\mathrm{D} \rho \mathrm{u} / \mu=0.106 \times 997.84 \times 105.76 \times 10^{-3} / 0.890 \times 10^{-3}=12569$ turbulent; From moody diagram, the friction factor, $\mathrm{f}=0.0065$; The friction head loss $=8 \mathrm{f}(\mathrm{L} / \mathrm{d})\left(\rho^{2} / 2\right) ;=8 \times 0.0065 \times[(0.4+1.6+0.01) / 0.106] \times\left[\left(997.84 \times 0.10576^{2} / 2\right] ;\right.$

$=5.50 \mathrm{~m}$

Diff $\mathrm{z}=1.6, \mathrm{P}_{1}-\mathrm{P}_{2}=0$

Pump head $=5.5+1.6+0.57=7.67 \mathrm{~m}$

therefore required pump power $=7.67 \times 9.81 \times 997.84 \times 0.936 \times 10^{-3}=\mathbf{7 0 . 3}$ Watts $(\mathrm{can}$ be easily supplied by solar)

\section{Table Roll}

$\mathrm{q}=\mathrm{Du}^{\mathrm{k}} / \mathrm{f}^{2}$ where $\mathrm{q}$ is the water removed by table per unit time and width $\mathrm{D}$ is the diameter of roll; $\mathrm{f}$ is drainage factor, $\mathrm{f}=6$ and $\mathrm{u}=$ speed of wire; Using efflux ratio $=$ speed of discharge jet/ speed of wire $=1$; Therefore $\mathrm{q}=\left[200 \times 10^{-3} \mathrm{x}\right.$ $\left.\left(105.76 \times 10^{-3}\right)^{1.2} / 6^{2}\right)=0.374 \times 10^{-3} \mathrm{~m}^{3} / \mathrm{s}$

\section{$\underline{\text { Rollers }}$}

$\mathrm{Q}=\mathrm{dLs} / 2.96$ where $\mathrm{d}$ is diameter of rollers, $\mathrm{L}$ is length of rolls and $\mathrm{s}$ is peripheral speed and $\mathrm{Q}$ is the capacity of rolls; $\mathrm{Q}=300 \times 10^{-3} \times 0.8 \times 110 \times 10^{-3}=\mathbf{8 . 9 2} \times 10^{-3} \mathbf{~ m 3} / \mathbf{s}$; 
finding the power required to drive each roller; for conveyer rollers the required power $=2.72$ watts for each roller, for the 9 rollers the total power required $=\mathbf{2 4 . 4 8}$ watts; $\mathrm{v}=$ wr hence $\mathrm{w}=\mathrm{v} / \mathrm{r}=110 \times 10^{-3} / 0.150=0.733 \mathrm{rad} / \mathrm{s}$; is to be attained in 0.5 sec hence $\alpha=1.467 \mathrm{rad} / \mathrm{s}^{2}$; Moment of inertia, $\mathrm{I}=0.5 \mathrm{~m}\left(\mathrm{R}_{1}{ }^{2}+\mathrm{R}^{2}{ }_{2}\right) ; \mathrm{I}=0.5 \times 181.73 \mathrm{x}$ $\left(0.15^{2}+0.125^{2}\right)=3.4642 \mathrm{kgm}^{2} ;$ Torque $=\mathrm{I} \alpha=3.4642 \times 1.4667=5.1 \mathrm{Nm} ; \mathrm{P}=\left(\mathrm{T}+\mathrm{T}_{\mathrm{c}}\right)$ $\mathrm{W}=251 \times 0.733=184$ Watts; The total power required to power the paper machine $=$ power of each roller $\mathrm{x}$ number rollers + conveyer rollers $=(184 \times 2)+24.48=\mathbf{3 9 2 . 4 8}$ Watts

The oven

For the design of the dryer oven, the results from the drying experiment conducted by Reardon (1994, p86) were used. The oven should receive hot air at a speed of $5 \mathrm{~m} / \mathrm{s}$ were the paper to be dried is on nylon felt with a tension of $1780 \mathrm{Nm}$.

\subsection{How it works}

The recycling machine is in 2 units which the cleaning unit and the paper machine unit

\section{Cleaning unit}

Is responsible for receiving pulp and then cleaning it

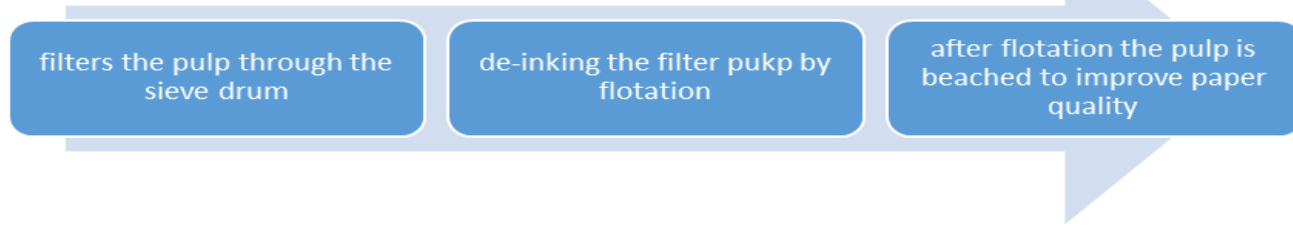

Fig. 4. Cleaning system

\section{Paper machine Unit}

Is responsible for the conversion of pulp into paper.

formation of paper web by feeding of pulp on to wire by pump

\section{dry pressing to} remove water

\section{removal of water by \\ heated rollers}

finishing of paper and finsl drying by use of hot sit

Fig. 5. Paper machine system 
The authors came up with the design that is solving the mentioned problem at the university and where necessarily required as shown in figure 5 .

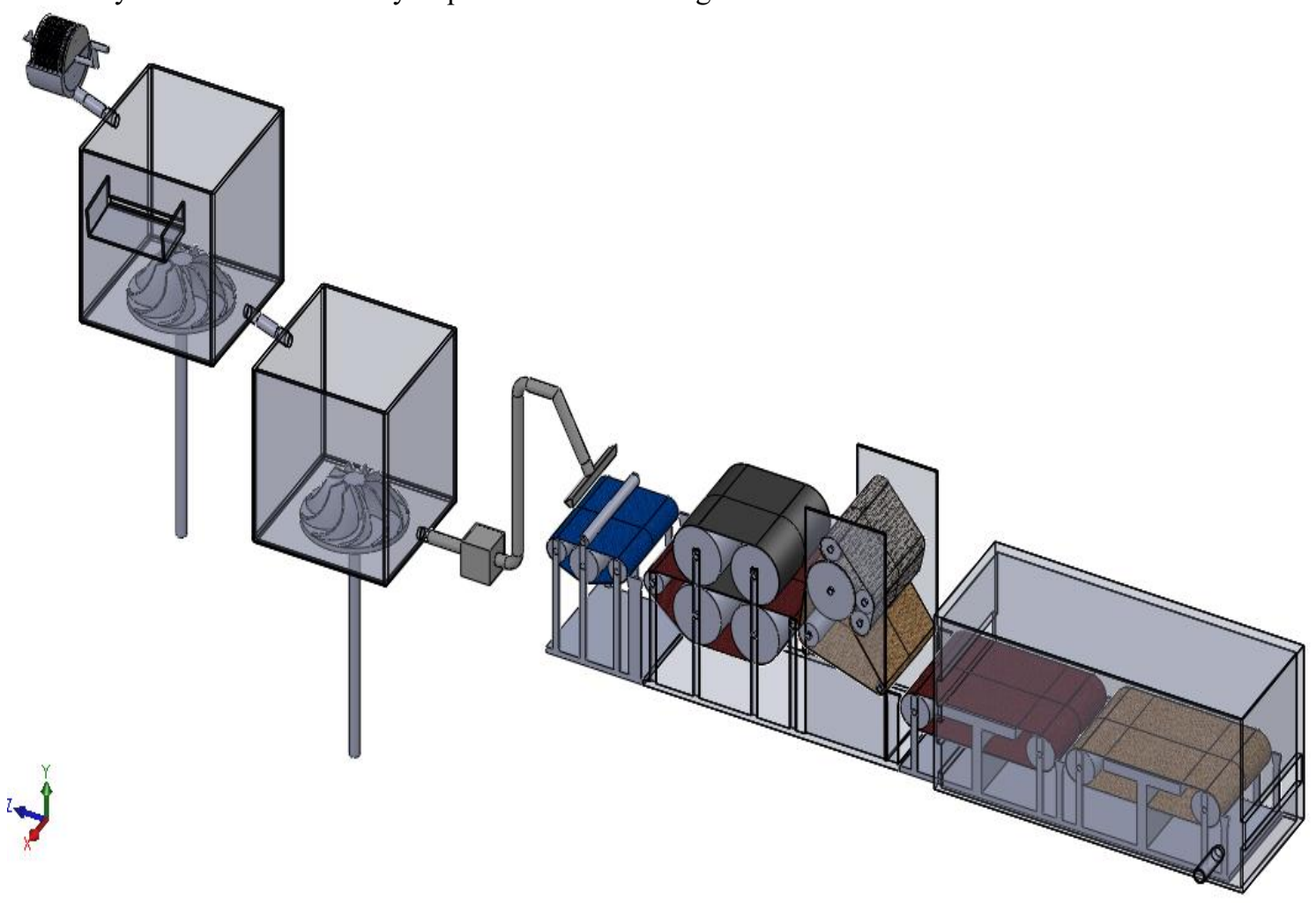

Figure 6. Designed manual paper recycling machine by the researchers.

\section{Conclusions and Recommendations}

\subsection{Conclusions}

The design is able to meet the necessary requirements and specifications. The operation of the machine does not require any specialised training hence an average person can operate it. Due to the small power, speed and load requirements of the machine, it is not expected to fail in its stipulated life time although special attention and maintenance will be required for the bearings and compression rollers which are the mostly likely components to fail during operation. The quality of recycled paper produced mainly the thickness, may be slightly be below the standard due to limitations of design power. Overally the continuous production of paper by use of 
the machine if quite effective when compared to other existing machines. Landfill and pollution problems in primary consumers of waste such as Universities and School will be considerably reduced by use of the machine and also the users will be benefit by meeting the demands of the paper market, allow the generation of income from waste and help to curb unemployment. Further study needs to be conducted so as to improve the speed and quality of paper to be improved.

\subsection{Recommendations}

It is recommended to use the machine in a suitable temperature environment of range $20^{\circ} \mathrm{C}$ to $40^{\circ} \mathrm{C}$ and the machine must be not exposed to rain at any given time. The flow rates of pulp feeding to the cleaning section and to the paper machine section as well as the machine design speeds should be within 3\% tolerance range. For good recycled paper quality all necessary stages of the machine such as flotation and bleaching should be conducted and also the raw material of the pulp to be feed into the machine should be have $90 \%$ of the total mass be high or medium quality print or writing white paper. The bearings and chains in the machine must be regular lubricated and maintained. A number of improvements can be made on this device such as an easy powering mechanism that can switch from man power to an electric power (motor) should be included in the implementation of the machine. The machine should cater for the safety of users due to exposure of high drying temperatures and a wet environment together with electric heating element and include a water retention or recycling system since paper recycling consumes large volumes of water The designers also recommends the further development and testing of this system into a functioning prototype to illustrate the functionality of the design therein and its relevance to the art of paper recycling.

\section{References}

1. Procarton, Recovery and recycling Available at: http://www.procarton.com/sustainability/sustainability/environment/recovery-andrecycling/ [Accessed 5 SEPTEMBER 2016].

2. City Data. (2017, march 11). Retrieved from http://www.citydata.com/forum/automotive/1777984-how-much-torque-couldaverage-human.html [Accessed 30 APRIL 2017]

3. Drelich, J., Pletka, J., Boyd, P., Raber, E., \& Herron, P. (2001, February 28). Michigan Tech University. Retrieved from Michigan Tech University Website: http://www.mse.mtu.edu/ jwdrelic/SME2001.pdf

4. Hart, P. W., \& Rudie, A. W. (2012). The Bleaching of Pulp. Norcross: TAPPI PRESS

5. Jiang, C., \& Ma, J. (2000). DE-INKING OF WASTE PAPER: FLOTATION. Enzymatic Deinking Technologies, 1-2.

6. Olson, J. A., .Pflueger, C. D., Delfel, S., Ollivier-Gooch, C., \& Martin, P. (2007). High Performance Foil Rotor Improves De-Ink Pulp Screening. Department of Mechanical Engineering, Pulp and Paper Centre, University of British Columbia, Canada, 1-2. 
7. Paper Online. (2016, December 13). Retrieved from http://www.paperonline.org/paper-making/paper-production/pulping [Accessed 4 AUGUST 2016]]

8. Pulp. (2016, December 20). Retrieved from Confederation of European Paper Industries Web site:

http://www.cepi.org/system/files/public/documents/publications/statistics/2014/FINA L\%20CEPI\%20Definitions\%20and\%20Concepts 0.pdf [Accessed 4 FERBRUARY 2017]

9. Pulp Paper Mill. (2015, February 16). Retrieved from http://www.pulppapermill.com/pulp-screening/ [Accessed 27 AUGUST 2016]

10. Reardon, S. (1994). A MATHEMATICAL MODEL FOR THE SIMULATION OF PAPER DRYING ENERGY CONSUMPTION. Pg. 85-87.

11. SILKROAD, n.d. THE HISTORY OF PAPER. [Online] Available at: http://www.silk-road.com/artl/papermaking.shtml [Accessed 4 AUGUST 2016].

12. Venditti, R., Paper Recycling Technology and Science, North Carolina State University, Forest Biomaterials Department.

13. Princeton University, The Pulp and Paper Making Processes, Available at: https://www.princeton.edu/ ota/disk1/1989/8931/893104.PDF [Accessed 5 JANUARY 2017] 